(C) ACM, 2021. This is the author's version of the work. It is posted here by permission of ACM for your personal use. Not for redistribution. The definitive version was published in 2021, 64 (3), pp. 73-77, https://doi.org/10.1145/3387106

\title{
Educational Interventions and Female Enrolment in IT degrees
}

The low number of female students pursuing IT degrees is an on-going problem despite efforts being made to address this issue. Various programs have been implemented to address solely female student representation or for students in general. However, to date, we know very little about their success in influencing students to enrol in these degrees. We have surveyed first year female students enrolled in IT degrees in Australia, asked them to identify programs they have participated in and state the perceived influence these programs had on their enrolment in their current degrees. We found that female students have participated in a variety of programs (on average being exposed to more than five programs) and the influence of these programs upon student decision making varies.

Keywords: programs, interventions, education, women in computing. 
Despite increasing awareness and efforts made to attract women to computing, they are still poorly represented in information technology (IT) careers [16]. The number of females graduating with an IT degree has consistently declined since 1984 when women were $34 \%$ of computer science graduates and they currently account for less than $20 \%$ of IT graduates in many countries $[8,14,15]$. These figures are replicated in the IT industry where women currently constitute a small part of the workforce $-24 \%$ in the United States, $18 \%$ in the UK, and 28\% in Australia [5, 6]. This lack of diversity in IT has repercussions for organizations and for society. There is increasing evidence that diversity in the workplace has a positive influence on productivity [2, 6]. For example, Herring [13] reports that organizations with high levels of gender diversity in teams have higher sales revenues, more customers and greater profitability than companies with predominantly male teams. Finding capable and confident people with IT skills is very difficult, and many employers struggle to recruit employees, particularly as the talent pool is restricted by the lack of qualified women. Encouraging more women into IT university courses would lead to an increase in both the size and diversity of a country's skilled workforce and address the growing shortfall of IT professionals in the industry. Women's participation in the field could also lead to monetary benefits. For example, in the European Union, it is estimated that existing initiatives [8] will improve women's participation in STEM-related fields and this will result in a 610-820 billion euros increase in the GDP [7]. Except for monetary benefits, narrowing the gender gap in STEM could also improve science and society [8].

Whilst many approaches have been widely implemented, many others have failed to systematically improve female participation at the university level [11] (and few have been successful). In the USA, the Computer Science degree at Carnegie Melon University reached almost 50\% in 2016, 2017 and 2018 [9] and Harvey Mudd College increased its enrollment of women pursuing a Computer Science degree from 10\% in 2006 to $40 \%$ in 2012 [1]. Frieze and Quesenberry [9] attributed the success to not changing the curriculum to be female-friendly but rather doing changes that improve the curriculum for everyone, changing the culture and institutional support for different programs. IT classes provided by the University of Cincinnati in the USA have also influenced some of the female students to register for the university's IT courses [10]. Others $[3,4]$ show that integrating creative expression in computer science units can help attract and retain more students. For example, the Technology, Arts, \& Media degree at the University of Colorado, Boulder achieved a 44.8\% female enrollment [3] and Computing in Arts at the College of Charleston attracted and retained $46 \%$ female students [4]. These initiatives are a positive step towards understanding how to address some of the issues that cause the low enrollment of women in IT units. In contrast to these studies, this paper focuses on existing programs and initiatives in Australia. The paper examines how female students enrolled in IT-related degrees perceived these initiatives. The need for further research in this area is highlighted also by Tims [19] who mentions that despite the multitude of initiatives and sustained efforts from many organizations, progress is slow. 


\section{Methodology}

The authors researched existing programs and initiatives aimed at promoting IT in Australia. A total of 36 initiatives were identified, some aimed only at girls while others were aimed at both male and female. A brief description of each initiative and geographic coverage is presented in Table 1 below. This is not an exhaustive list of initiatives. To avoid some influential programs being missed during our research, the participants were also asked to provide further details about other programs they were involved in.

Data were collected through the use of a questionnaire. These were distributed to first-year female students enrolled in computing-related degrees in Australia. The questionnaire uses a combination of closed and open-ended questions. The participants were asked demographic questions (e.g. in which state they lived during high school) and were asked to state what initiatives they participated in (if any) during high school. Furthermore, they were asked to expand whether they found that any of these initiatives motivated them to enroll in a computing degree. The open-ended questions were analyzed using thematic analysis [12].

Table 1 Brief Descriptions of the Initiatives and their Locations (ACT - Australian Capital Territory, NSW -

New South Wales, NT - Northern Territory, QLD - Queensland, VIC - Victoria, SA - South Australia, TAS -

Tasmania, WA - Western Australia)

\begin{tabular}{|c|c|c|}
\hline Initiative & Description & $\begin{array}{l}\text { Geographic } \\
\text { Coverage }^{1}\end{array}$ \\
\hline Bebras & $\begin{array}{l}\text { An international competition for students in Year } \\
3-12 \text { to promote students' computational thinking. }\end{array}$ & National/International \\
\hline Big Day In & $\begin{array}{l}\text { A conference organized by university students for } \\
\text { Year 9-12 students interested in careers in ICT } \\
\text { and technology. }\end{array}$ & NSW, Vic, QLD, WA \\
\hline Career Fairs & $\begin{array}{l}\text { Career fairs to display different career } \\
\text { opportunities to senior secondary students. }\end{array}$ & National \\
\hline $\begin{array}{l}\text { Club } \\
\text { Kidpreneur/name } \\
\text { change to Entropolis } \\
\text { HQ }\end{array}$ & $\begin{array}{l}\text { A program aimed to encourage Years 5-10 } \\
\text { students in entrepreneurial thinking and improve } \\
\text { knowledge about finances, business acumen and } \\
\text { other skills. }\end{array}$ & National \\
\hline Code Club & $\begin{array}{l}\text { Coding club for children aged } 9-13 \text { years run by } \\
\text { volunteers. }\end{array}$ & National/International \\
\hline Code Like a Girl & $\begin{array}{l}\text { A social enterprise to develop girls aged 8-12 } \\
\text { programming skills through a three day camp. }\end{array}$ & National \\
\hline
\end{tabular}

1 Where the initiatives were online and there were no restrictions to where the participants need to be in order to enroll they are marked as national in the table. 


\begin{tabular}{|c|c|c|}
\hline CoderDojo & $\begin{array}{l}\text { Computer programming clubs for students aged } \\
\text { between } 7 \text { and } 17 .\end{array}$ & $\begin{array}{l}\text { QLD, NSW, VIC, } \\
\text { WA/International }\end{array}$ \\
\hline $\begin{array}{l}\text { Computer Games } \\
\text { Boot Camp }\end{array}$ & $\begin{array}{l}\text { An industry engagement event for students in } \\
\text { Years 9-12 to learn about how games are designed } \\
\text { and developed with insights into IT career paths. }\end{array}$ & VIC \\
\hline ECOMAN & $\begin{array}{l}\text { Aims to familiarize students about business } \\
\text { concepts by using a business simulation program. }\end{array}$ & QLD \\
\hline Endeavour & $\begin{array}{l}\text { Workshop and a design expo aiming to familiarize } \\
\text { students with engineering. }\end{array}$ & VIC \\
\hline $\begin{array}{l}\text { E.X.I.T.E. - } \\
\text { Exploring interests } \\
\text { in Technology and } \\
\text { Engineering }\end{array}$ & $\begin{array}{l}\text { Camps for girls in Years 8-10 aimed to increase } \\
\text { students' interest in STEM. They also explore the } \\
\text { opportunities of contributing to the community } \\
\text { and being creative in technology and engineering } \\
\text { careers. }\end{array}$ & $\begin{array}{l}\text { QLD, VIC, } \\
\text { NSW/International }\end{array}$ \\
\hline $\begin{array}{l}\text { Females in } \\
\text { Technology and } \\
\text { Telecommunications }\end{array}$ & $\begin{array}{l}\text { A network aiming to inspire and to support } \\
\text { women in technology and communications. }\end{array}$ & National \\
\hline $\begin{array}{l}\text { FIRST LEGO } \\
\text { League }\end{array}$ & $\begin{array}{l}\text { Children in Years } 4-9 \text { solve real-world projects. In } \\
\text { the process they have to build a robot and } \\
\text { program it using LEGO }{ }^{\circledR} \text { Mindstorms to solve an } \\
\text { annual challenge. }\end{array}$ & National/International \\
\hline $\begin{array}{l}\text { FIRST Robotics } \\
\text { Competition }\end{array}$ & $\begin{array}{l}\text { Students in Years 9-12 design, build, program an } \\
\text { industrial robot and compete against other teams } \\
\text { to solve an annual challenge. }\end{array}$ & National/International \\
\hline $\begin{array}{l}\text { Girl GeekAcademy - } \\
\text { \#MissMakesCode }\end{array}$ & $\begin{array}{l}\text { \#MissMakesCode is an initiative to build } \\
\text { confidence and self-efficacy in the areas of } \\
\text { algorithmic thinking, programming and coding for } \\
\text { young girls aged 5-8 years. }\end{array}$ & VIC/NSW \\
\hline $\begin{array}{l}\text { Girl Power in } \\
\text { engineering \& IT } \\
\text { program }\end{array}$ & $\begin{array}{l}\text { This program is specifically for girls and targets } \\
\text { Year } 9 \text { students to attend a } 3 \text { day camp. In the } \\
\text { following year, the students undertake work } \\
\text { experience and in Year, } 11 \text { and } 12 \text { the participants } \\
\text { are given university student mentors. }\end{array}$ & VIC \\
\hline $\begin{array}{l}\text { Girls Programming } \\
\text { Network }\end{array}$ & $\begin{array}{l}\text { A program run by girls for girls as a one-day } \\
\text { workshop. As part of the workshop, they develop } \\
\text { games, mobile apps and learn about digital media } \\
\text { and encourage high school girls to attend. }\end{array}$ & NSW \\
\hline Hour of code & Events during which the students code. & National/International \\
\hline
\end{tabular}




\begin{tabular}{|c|c|c|}
\hline $\begin{array}{l}\text { Indigenous Girls } \\
\text { STEM Academy }\end{array}$ & $\begin{array}{l}\text { Coding clubs, competitions and scholarship for } \\
\text { high achieving indigenous girls in Years 8-11 to } \\
\text { suceed in STEM careers. }\end{array}$ & NSW/WA \& QLD \\
\hline $\begin{array}{l}\text { Computational and } \\
\text { Algorithmic } \\
\text { Thinking (CAT) | } \\
\text { AMT }\end{array}$ & $\begin{array}{l}\text { This is a one hour problem-solving competition } \\
\text { aimed at students in Years 5- } 12 \text { is designed to } \\
\text { promote different ways of thinking including } \\
\text { computational and algorithmic skills. }\end{array}$ & National \\
\hline $\begin{array}{l}\text { Informatics } \\
\text { Olympiad }\end{array}$ & $\begin{array}{l}\text { The Australian Informatics Olympiad (AIO) is an } \\
\text { open national computer programming competition } \\
\text { held annually for students up to year } 10 \text { and } \\
\text { senior students up to Year } 12 \text {. The top four } \\
\text { students in Australia will be asked to represent } \\
\text { Australia at the International Olympiad }\end{array}$ & National/International \\
\hline $\begin{array}{l}\text { (BrainSTEM) } \\
\text { Innovation } \\
\text { Challenge }\end{array}$ & $\begin{array}{l}\text { Students in Years } 9 \text { or } 10 \text { are paired with a mentor } \\
\text { and they work together for } 12 \text { weeks in a STEM } \\
\text { related research environment. }\end{array}$ & VIC \\
\hline $\begin{array}{l}\text { Minecraft } \\
\text { Competition }\end{array}$ & $\begin{array}{l}\text { Competition aiming to engage youth with social } \\
\text { "hot trends". It aims to sparks creativity and } \\
\text { collaboration by embracing new technology. }\end{array}$ & National \\
\hline NCSS Challenge & $\begin{array}{l}\text { Aimed at students in Years } 5-12 \text {, to undertake this } \\
\text { competition with training running for five weeks } \\
\text { to learn or further develop their programming } \\
\text { experience. }\end{array}$ & National \\
\hline $\begin{array}{l}\text { NCSS Summer } \\
\text { School }\end{array}$ & $\begin{array}{l}\text { A ten day summer school holiday intensive } \\
\text { program aimed at Year } 11 \text { students going into } \\
\text { Year } 12 \text { to develop their skills in programming, } \\
\text { robotics and web design. }\end{array}$ & National \\
\hline $\begin{array}{l}\text { RACQ Technology } \\
\text { Challenge } \\
\text { Maryborough }\end{array}$ & $\begin{array}{l}\text { Students compete and learn the use of technology } \\
\text { and teamwork by building a vehicle. }\end{array}$ & VIC \\
\hline Robocup Junior & $\begin{array}{l}\text { Aims to introduce RoboCup Junior to primary and } \\
\text { secondary school children to encompass } \\
\text { engineering and IT skills. }\end{array}$ & $\begin{array}{l}\text { QLD, NSW, VIC, } \\
\text { WA, SA, TAS, } \\
\text { ACT/International }\end{array}$ \\
\hline Robogals & $\begin{array}{l}\text { Program aimed at primary and secondary school } \\
\text { girls with the aim to improve their participation } \\
\text { and confidence to work in engineering, science }\end{array}$ & $\begin{array}{l}\text { QLD, NSW, VIC, } \\
\text { WA, SA, } \\
\text { ACT/International }\end{array}$ \\
\hline
\end{tabular}




\begin{tabular}{|l|l|l|}
\hline & and technology, & \\
\hline RoboGirls & Female robotics competition aimed at girls. & - \\
\hline $\begin{array}{l}\text { (Australian) STEM } \\
\text { Video Game }\end{array}$ & $\begin{array}{l}\text { Aimed at students in Years 5-12 this challenge } \\
\text { aims to address students perceptions of STEM } \\
\text { subjects. }\end{array}$ & National \\
\hline SuperDaughter Day & $\begin{array}{l}\text { Girls aged 5-12 years of age participate in hands } \\
\text { on activities, including virtual and augmenting } \\
\text { reality, app design, technology and wearables } \\
\text { along with their parents. They also meet role } \\
\text { models from industry. }\end{array}$ & National/International \\
\hline $\begin{array}{l}\text { Tech Girls are } \\
\text { Superheroes }\end{array}$ & $\begin{array}{l}\text { Girls aged between 7-17 years of age compete by } \\
\text { solving a problem through the development of a } \\
\text { mobile app and a business plan. }\end{array}$ & $\begin{array}{l}\text { National \& New } \\
\text { Zealand }\end{array}$ \\
\hline $\begin{array}{l}\text { Tech School } \\
\text { experience/workshop }\end{array}$ & $\begin{array}{l}\text { Hands-on workshops on engineering and IT for } \\
\text { school students. }\end{array}$ & $\begin{array}{l}\text { VIC } \\
\text { Women in } \\
\text { Technology }\end{array}$ \\
\hline $\begin{array}{l}\text { Young ICT } \\
\text { Explorers }\end{array}$ & $\begin{array}{l}\text { Students to women already working in the field. } \\
\text { Acompetition which students from Years 3-12 } \\
\text { students showcase their projects which are judged } \\
\text { according to the following criteria: Creativity and } \\
\text { Innovation, Quality and Completeness, Level of } \\
\text { Difficulty and Documentation. }\end{array}$ & QLD \\
\hline
\end{tabular}

\section{Participants}

A total of 119 participants who identified themselves as females completed the survey. Among these, we eliminated: (a) the ones who did not fully complete the questionnaires and (b) the ones who lived in Australia for less than one year and did not complete their secondary education in Australia. They were eliminated as they very likely not exposed to the programs. This led to 108 participants included in the analysis. Our final sample size included $8 \%$ of students that have completed their secondary education abroad but have lived in Australia for more than one year.

Most of the participants lived in Australia all their life (72\%) and all of them were first-year undergraduate students enrolled in an IT degree (e.g. Computer Science, Business Information Systems). Although we did not plan for it, our sample size included participants completing their education across eight Australian states and Territories. We had more participants from Victoria and New South Wales than other states, but these are also the most populated states in Australia.

\footnotetext{
2 Possibly the same initiative as Robogals
} 


\section{Findings}

\section{Exposures to programs}

Our participants were exposed to a variety of programs (on average being exposed to 5.4 programs). Figure 1 presented on the left-hand side the programs the participants had engaged with. Also, the participants mentioned two other programs not included in our questionnaire. The most exposed program (on the same level to Career Fairs) was Women in Technology to which $36 \%$ of the participants took part in. This was followed by Big Day In and Females in Technology both with 24\%, Code like a Girl (23\%) and Code Club (23\%).

\section{Influential Programs}

The second aim of our study was to determine whether the participants perceived these programs as being useful in influencing them to enroll in computing/IT type degrees. The participants had mixed feelings about the programs but overall, they have influenced many of the participants. Some of the participants felt strongly about the influence the programs had while others felt that the programs probably had some influence or at least motivated them to find more about the field. Others felt that there were other factors (e.g. current workplace) that influenced them and not necessarily the programs. We grouped all the replies into positive and negative ones. As the participation in the programs was not uniform, Figure 1 presents the replies relative to the number of participants in the program.

The most influential program for our participants was Women in Tech. A total of $50 \%$ of the participants in the study and program mentioned that they were influenced or probably influenced by this program. This was followed closely by Females in Technology and Telecommunications (48\%). Although programs dedicated to females only have been perceived as the most influential, other programs such as Code Club and Computer Games Boot Camp also ranked highly. 


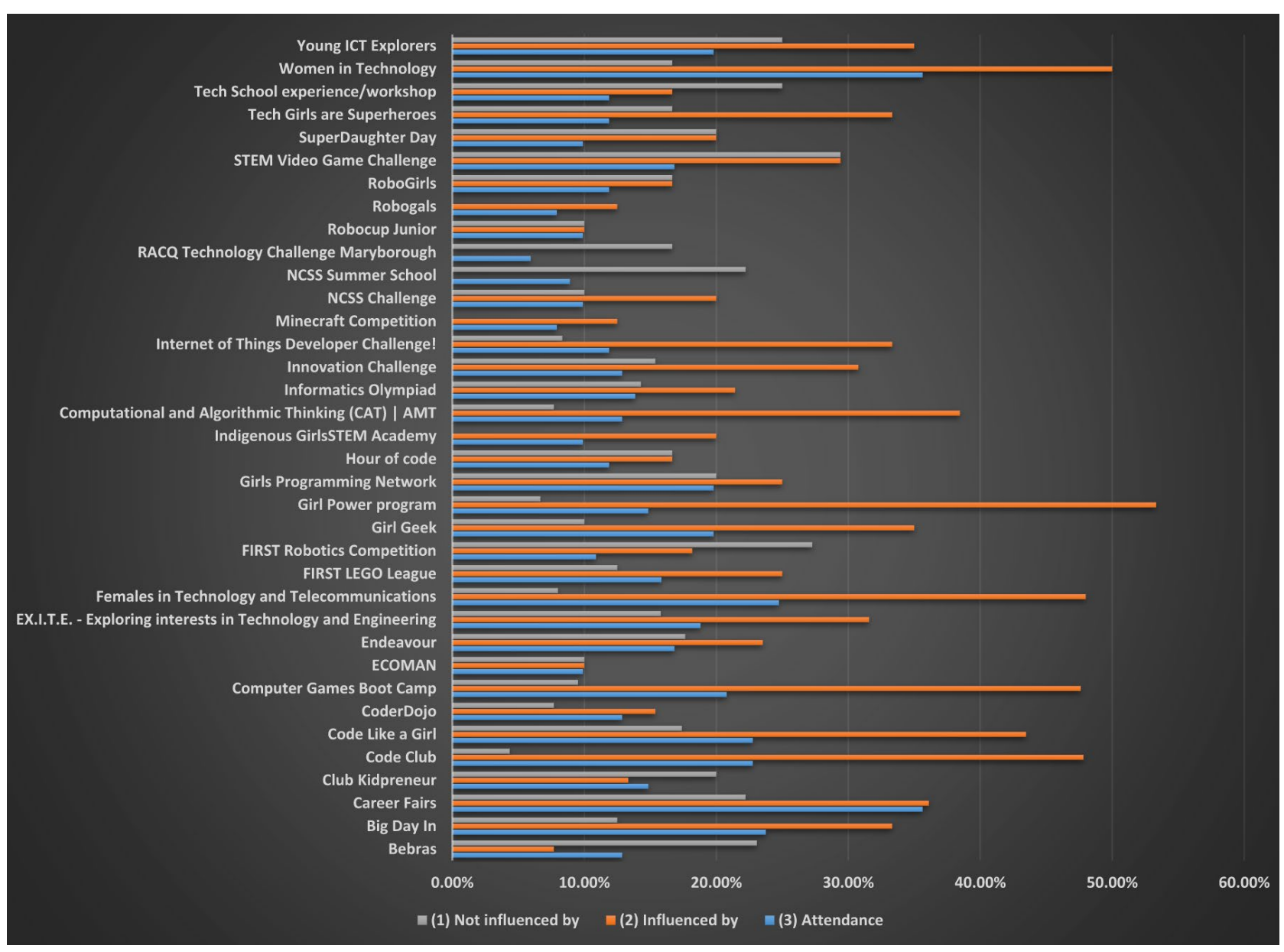

Figure 1 Event attendance and influence on enrolling in a computing like degree: (1) Percentage of participants that attended the event; (2) Among those who participated in the event, percentage that felt influenced or potentially influenced by the event to enroll in a computing like degree; (3) Among those that participated in the event, percentage who felt that the event did not have a role in their enrollment in a computing related degree

\section{Moving Forward}

This article adds further insights into how programs and interventions influence female students' decision to enroll in IT-related degrees. A survey was targeted at first-year female students to report on which, if any, outreach programs influenced their decision to enroll in an IT degree. We found that there was no single model of intervention and that different programs influenced different people. This variety of offerings contributed to attracting a diverse pool of students. Notably, those programs aimed specifically at females were perceived to potentially have more influence on the decision to enroll in an IT degree. This does not negate the influence of mixed gender programs but does highlight the importance of having programs aimed only at female students alongside more generalised outreach programs. Additionally, students had often participated in more than one program and further research in determining how they personally 
rank the effectiveness of different programs and why they attended them.

Further studies are also needed to confirm whether these findings can be replicated more broadly and with an exhaustive list of existing initiatives. For example, this study only addresses the perceptions of current female IT students and does not consider how other students, who may not have been successful in enrolling in an IT degree, perceived the value of the programs. A further factor of interest is whether positive participation in these programs is instrumental in the decision to study IT or whether participation affirms an existing intention.

Finally, this study included initiatives at both National and State level. The most popular initiatives were those delivered at a national level which are more widely offered, although we have no evidence that availability affects the findings. Further research is needed to determine the common and unique characteristics of each of these initiatives, how they were advertised and what support was made available to schools to encourage attendance. This would enable more effective targeting of initiatives to overcome the perennial problem of recruiting women into IT programs.

\section{Acknowledgements}

This research has been partially funded by the Australian Council of Deans of Information and Communications Technology. We want to thank Thomas Stockdale who has helped with the participants' recruitment for the study and the Australian Academy of Science which has provided information about some of the different initiatives running in Australia.

\section{References}

[1] Alvarado, C., Dodds, Z., \& Libeskind-Hadas, R. (2012). Increasing women's participation in computing at Harvey Mudd College. ACM Inroads, 3(4), 55-64.

[2] Australian Computer Society. (2015). The Promise of Diversity: Gender Equality in the ICT Profession.

Retrieved

from

http://acs.org.au/_ data/assets/pdf_file/0003/87681/ACS-Gender-Equality-FINAL.pdf

[3] Barker, L. J., Garvin-Doxas, K., \& Roberts, E. (2005). What can computer science learn from a fine arts approach to teaching?. ACM SIGCSE Bulletin, 37(1), 421-425.

[4] Bares, W. H., Manaris, B., McCauley, R., \& Moore, C. (2019, February). Achieving Gender Balance through Creative Expression. In Proceedings of the 50th ACM Technical Symposium on Computer Science Education (pp. 293-299). ACM. 
[5] Deloitte. (2016). Technology, Media \& Telecommunications Predications 2016. Retrieved from http://www2.deloitte.com/content/dam/Deloitte/global/Documents/Technology-Media-Tele communications/gx-tmt-prediction-2016-full-report.pdf

[6] Deloitte Access Economics. (2015). Australia's digital pulse: key challenges for our nation: digital skills, jobs and education. Retrieved from: http://www2.deloitte.com/content/dam/Deloitte/au/Documents/Economics/deloitte-au-econ omics-australias-digital-pulse-240614.pdf

[7] EIGE. (2018). Economic case for gender equality in the EU. Retrieved from: https://eige.europa.eu/gender-mainstreaming/policy-areas/economic-and-financial-affairs/ec onomic-benefits-gender-equality

[8] Fatourou, P., Papageorgiou, Y., \& Petousi, V. (2019). Women are needed in STEM: European policies and incentives. Communications of the ACM, 62(4), 52-52.

[9] Frieze, C., \& Quesenberry, J. L. (2019). How computer science at CMU is attracting and retaining women. Communications of the ACM, 62(2), 23-26.

[10] Fritz, J., Wulf, T., Matthews, M., \& Scott, J. (2015, September). University of Cincinnati and Saint Ursula Academy Partnership: Introducing Female High School Students to the Field of Information Technology. In Proceedings of the 16th Annual Conference on Information Technology Education (pp. 9-14). ACM.

[11] Gorbacheva, E., Beekhuyzen, J., vom Brocke, J., \& Becker, J. (2019). Directions for research on gender imbalance in the IT profession. European Journal of Information Systems, 28(1), 43-67.

[12] Guest, Greg, Kathleen M. MacQueen, and Emily E. Namey. Applied thematic analysis. Sage Publications, 2011.

[13] Herring, C. (2009). Does diversity pay?: Race, gender, and the business case for diversity. American Sociological Review, 74(2), 208-224.

[14] Hutchinson, J., \& Tadros, E. (2014). Shortage of IT graduates a critical threat [Press release]. Retrieved from http://www.afr.com/p/technology/shortage_of_it_graduates_critical_tOuFEdBporFCdLIon $\underline{\text { KFJFJ }}$

[15] NCWIT (Producer). (2014). Women and Information Technology By the Numbers. Retrieved from http://www.ncwit.org/sites/default/files/resources/btn_02282014web.pdf

[16] NSF (2018) Science and Engineering Indicators. National Science Foundation. Retrieved 23 August 2019 from: https://nsf.gov/statistics/2018/nsb20181/report

[17] OECD. (2014). Education at a Glance 2014: OECD Indicators. Retrieved from 
http://dx.doi.org/10.1787/eag-2014-en

[18] OECD. (2015). Students, Computers and Learning: Making the Connection, PISA. Retrieved from http://dx.doi.org/10.1787/9789264239555-en

[19] Tims, J. L. (2018). Achieving gender equity: ACM-W can't do it alone. Communications of the $A C M, 61(2), 5-5$. 